\title{
PRESENTATION
}

\section{Intro to this special issue: refugees/displaced people in the workplace}

\author{
Ph.D. Sharon L. Segrest ${ }^{1}$ \\ PH.D. AMY E. HURLEY-HANSON ${ }^{2}$ \\ Ph.D. Cristina M. Giannantonio ${ }^{2}$
}

\author{
${ }^{1}$ University of South Florida / Muma College of Business, St. Petersburg - FL, United States of America \\ ${ }^{2}$ Chapman University / ARgrros School of Business ANd ECONOMICS, ORANGe - CA, UNITEd STATES Of AMERICA
}

\begin{abstract}
This special issue focuses on refugees' experiences and displaced people across a diverse set of ethnicities and circumstances. The growing number of refugees and displaced people and the work and life difficulties they face are central social issues in the world today. This special issue will explore how refugees and displaced people in Brazil can be fully integrated, socialized, engaged, embraced, and affirmed into the workplace and society. Research is presented on the experiences of refugees and displaced people, a growing but under-researched segment of the world's population. Little is known about refugees' career experiences and displaced people and how organizations, leaders, and policymakers can assist them in finding work, maintaining employment, and creating positive life outcomes. There are 12 articles included in this special issue. They focus on three areas of refugees in the workplace. The first area explores biases in the perceptions of refugees based on factors such as skin complexion, countries of origin, and race. The second area presents research that elaborates on the theme of displacement of refugees and barriers to integration, inclusion, social recognition, and belonging. The third area examines ways in which refugees have been integrated and acculturated into Brazilian society, often through the assistance of NGOs or through the efforts of managers in the workplace. It is our hope that the research presented in this special issue will increase interest in this important topic and lead to additional future research related to reducing barriers to integration and acculturation that refugees and displaced people face.
\end{abstract}

Keywords: Refugees. Careers. Refugee integration. Refugee acculturation. NGOs.

\section{Introdução à edição especial: pessoas refugiadas ou deslocadas no ambiente de trabalho}

\section{Resumo}

Esta edição especial se concentra nas experiências de refugiados e deslocados em meio a um conjunto diversificado de etnias e circunstâncias. O número crescente de pessoas nessas condições, bem como suas dificuldades na vida e no trabalho, são questões sociais centrais no mundo de hoje. A presente edição traz estudos que exploram como refugiados e deslocados - uma população ainda pouco estudada, mas crescente em todo o planeta - podem ser totalmente integrados, socializados, engajados, acolhidos e afirmados no local de trabalho e na sociedade, considerando o contexto brasileiro. Pouco se sabe sobre as experiências de carreira dessa população e sobre como organizações, lideranças e formuladores de políticas públicas podem contribuir para que ela possa encontrar trabalho, manter empregos e alcançar bons resultados na vida. São apresentados aqui 12 artigos, reunidos em três áreas relacionadas ao tema dos refugiados e seu local de trabalho. A primeira área explora preconceitos nas percepções a respeito de pessoas refugiadas em base a fatores como o tom da pele, país de origem e raça. A segunda apresenta pesquisas que abordam o deslocamento de refugiados e as barreiras à integração, inclusão, reconhecimento social e pertencimento. A terceira área, finalmente, examina com os refugiados têm sido integrados e aculturados na sociedade brasileira, muitas vezes por meio da assistência de organizações da sociedade civil ou pelos esforços de gestores no local de trabalho. Esperamos que as pesquisas apresentadas nesta edição especial contribuam para ampliar o interesse nesse importante tópico, inspirando futuros estudos que possam levar à redução das barreiras enfrentadas pelos refugiados e deslocados em seus processos de integração e aculturação.

Palavras-chave: Refugiados. Carreiras. Integração de refugiados. Aculturação de refugiados. Organizações da sociedade civil.

\section{Introducción a la edición especial: personas refugiadas o desplazadas en el lugar de trabajo}

\section{Resumen}

Esta edición especial se centra en las experiencias de los refugiados y desplazados en medio de un conjunto diverso de etnias y circunstancias. El creciente número de personas en estas condiciones, así como sus dificultades en la vida y en el trabajo, son cuestiones sociales centrales en el mundo actual. Los estudios publicados en esta edición exploran cómo los refugiados y las personas desplazadas -una población aún poco estudiada, pero que crece en todo el planeta - pueden ser plenamente integrados, socializados, involucrados, acogidos y afianzados en el lugar de trabajo y en la sociedad, considerando el contexto brasileño. Poco se sabe sobre las experiencias profesionales de esta población y sobre cómo organizaciones, líderes y formuladores de políticas públicas pueden contribuir a que esta encuentre trabajo, mantenga su empleo y logre buenos resultados en la vida. Aquí se presentan 12 artículos reunidos en tres áreas relacionadas con el tema de los refugiados y su lugar de trabajo. La primera área explora los prejuicios en las percepciones con respecto a los refugiados en función de factores como el tono de piel, el país de origen y la raza. La segunda presenta investigaciones que abordan el desplazamiento de refugiados y las barreras a la integración, inclusión, reconocimiento social y pertenencia. Finalmente, la tercera área examina cómo los refugiados han sido integrados y aculturados en la sociedad brasileña, a menudo a través de la asistencia de organizaciones de la sociedad civil o mediante los esfuerzos de gestores en el lugar de trabajo. Esperamos que las investigaciones presentadas en esta edición especial contribuyan a incrementar el interés en este importante tema e inspiren futuros estudios que puedan conducir a la reducción de las barreras que enfrentan los refugiados y desplazados en sus procesos de integración y aculturación.

Palabras clave: Refugiados. Carreras. Integración de refugiados. Aculturación de refugiados. Organizaciones de la sociedad civil. 
This special issue focuses on refugees' and displaced peoples' experiences across a diverse set of ethnicities and circumstances. The growing number of refugees and displaced people and the work and life difficulties they face is a central social issue in the world today. This special issue will explore how refugees and displaced people in Brazil can be fully integrated, socialized, engaged, embraced, and affirmed into the workplace and society. This special issue called for submissions which present research on the experiences of refugees and displaced people, a growing but under-researched segment of the world's population.

Little is known about refugees' and displaced peoples' career experiences and how organizations, leaders, and policymakers can assist them in finding work, maintaining employment, and creating positive life outcomes. Statistics from the United Nations Refugee Agency on the number of refugees and displaced people are staggering. The United Nations High Commissioner for Refugees estimates there are more than 80 million forcibly displaced persons worldwide, with 30 to 34 million of those being children under 18 years of age. Close to 46 million people are internally displaced, while 26.3 million are refugees and 4.2 million are asylum-seekers (United Nations High Commissioner for Refugees [UNHCR], 2021). Developing countries are hosting approximately $86 \%$ of the world's refugees, while the least developed countries open their borders to $28 \%$ of refugees. Over $67 \%$ of refugees come from the following five countries: Syria (6.6 million), Venezuela (3.7 million), Afghanistan (2.7 million), South Sudan (2.3 million), and Myanmar (1.0 million).

According to Macro Trends data, Brazil's refugee statistics reveal a 190.55\% increase in refugees from 2018 to 2019, from 11,304 official refugees in 2018 to 32,844 official refugees in 2019 (Macro Trends, 2021). Refugees to Brazil include people from Venezuela, Haiti, the Middle Eastern countries such as Syria, and several African countries. In 2019 Brazil received 81,485 asylum applications, according to the UNHCR. Most of these applications came from Venezuela and Haiti. Since the 2010 Haitian earthquake, over 100,000 Haitians have sought refuge in Brazil. Venezuelans have been fleeing their country due to severe socio-economic problems resulting in starvation, health problems, insecurity, violence, political unrest, threats, and human rights issues.

In recent years, according to the UNHCR, the Venezuelan crisis has become one of the largest displacement crises in the world, with over 5.4 million refugees and migrants, over 800,000 asylum seekers, and over 2.5 million people from Venezuela living under legal forms of stay (UNHCR, 2020). Most of these displaced Venezuelans are now living in Latin American and Caribbean countries. United Nations investigators claim the Venezuelan government has "committed egregious violations," including killings, torture, violence, and disappearances of people in an effort to suppress political opposition (Rueda, 2020). The pandemic has made the situation even more desperate for those trying to flee Venezuela since many of the shelters along routes of escape have been closed, and people who might normally offer assistance are worried about being infected with COVID-19.

Some people fleeing Venezuela are forced to sleep on the pavement in temperatures that are well below freezing while trying to reach warmer temperatures (Rueda, 2020). Approximately a quarter of those traveling have children (International Organization for Migration, 2021). Workers from organizations such as Caritas France are supplying some of these refugees with water, energy bars, and gear to help with the cold. Those fleeing Venezuela were fortunate if they could earn approximately $\$ 2$ a month, and they would spend all of their wages on basic supplies such as a kilo of rice when available. In neighboring countries, wages are approximately 100 times higher, providing a huge incentive to leave Venezuela (Rueda, 2020).

This large increase in the number of refugees may lead to backlash from citizens of the host countries. This backlash may occur in the form of prejudice and discrimination based on factors such as skin color, language, accent, race, religion, and country of origin. In this special edition, several articles discuss racism and other types of discrimination that can create barriers to integration that displaced people have experienced in Brazil. Several articles delve into the integration and acculturation of refugees, often through the employment process and sometimes with the assistance of various Non-Governmental Organizations (NGOs).

Ager and Strang's (2008) framework of integration indicates that employment is extremely important for refugee integration since it influences many other issues such as self-esteem, self-reliance, economic independence, and planning for the future. Important elements of successful integration involve achievement and access to employment across various sectors, housing, education, health, citizenship rights, social connections within the community, and overcoming barriers to connection and 
resettlement related to the local culture and language. In some cases, governments do not have integration plans for refugees (e.g., housing refugees together, isolating them from the rest of the population), which has proven to be ineffective for long-term acculturation. Productive discussion of the issues being faced by displaced people is critical for coherent policy development and the effective resettlement and integration of refugees and other displaced people.

The call for papers for this special issue called for research examining the myriad issues faced by refugees and the programs designed to help them gain job skills and find employment. Research questions for this special issue include: What unique work-related challenges are displaced people facing? How do displaced people experience and manage their careers? How can organizations improve the career, work, and life outcomes for refugees and displaced people? and What kinds of educational and training programs may prove efficacious in improving career and life outcomes for these individuals? This special issue includes 12 articles that examine issues related to racism, prejudice, and discrimination against refugees in Brazil and efforts to integrate and acculturate refugees into Brazilian society.

The first three articles deal with biases in the perceptions of refugees based on factors such as skin complexion, countries of origin, and race. The opening paper, Your home, my refuge: on being a refugee in Brazil, adds to the South-South migration literature by interviewing 24 refugees employed in small and medium-sized enterprises in São Paulo. The interview data was analyzed with Critical Discourse Analysis resulting in three a priori categories: discursive, social, and textual. The authors found that social practices varied based on their countries of origin, gender, skin complexion, and race. Three different roles were revealed: victim, faker, or hero. Additional textual analysis indicated resistance to the lower social status afforded to refugees within Brazilian society.

The second paper, Relationship between precarious work and racism for migrants in Brazil, examined data from questionnaires administered to 274 refugee participants in the cities of Passo Fundo and Erechim from the following countries: Venezuela, Haiti, Bangladesh, and Senegal. Data were obtained utilizing personal contacts and the snowball technique. Results showed that precarious work significantly affected immigrants' perceptions of racism due to ethnicity (e.g., religion, national origin) or darker skin color. In addition, discrimination at work moderated the relationship between precarious work and immigrants' perception of racism. The authors noted that the segregation movement is currently quite strong in Brazil and that public policies are needed to address racial inclusion and that organizations, nonprofits, and managers should also be aware of these problems since acceptance in the workplace is a primary means of integrating into society.

The third paper, South-South migration: a study on refugees working in Brazilian small and medium enterprises, analyzed refugees' integration in Brazil from the global South, expanding on the South-South migration literature and stereotypes of refugees in Brazil. Semi-structured interviews and observations were conducted with 28 respondents, including seven refugee employees, including 2 Haitians, 1 Nigerian, 1 Congolese, and 1 Beninese; 7 Brazilian employers in various sectors; and 14 Brazilian coworkers. It was found that Brazilian employers and workers tended to stereotype black refugees from various African countries and Haiti into one group of "black Africans" based on their skin color, demonstrating a lack of knowledge about the cultural and geographic differences of these refugees. This lack of knowledge makes it more challenging for refugees to integrate in the workplace. Language barriers contributed to communication problems in the workplace, and there was a general distrust of refugees and disrespect of those with different customs, such as Muslim refugees eating Halal food. The authors suggest additional managerial incentives to successfully integrate refugees in the workplace and cultural diversity training for Brazilian employers and employees who work with refugees could help to mitigate these problems.

The next set of articles elaborate on the theme of displacement of refugees and barriers to integration, inclusion, social recognition, and belonging. The fourth article, Why is it so hard to belong? The difficulties of refugees in their integration processes within Brazilian society and labor market utilized qualitative analyses of in-depth interviews of refugees of various nationalities and genders in the city of Rio de Janeiro. Results revealed a gap between public policies and practices involving refugees in the workplace. In addition to perceived discrimination, refugees had problems related to differences in the educational system in Brazil versus the educational system in the refugees' home countries and related problems obtaining diploma equivalencies. Regardless of the challenges refugees face integrating into Brazilian society, the respondents indicated their intentions to remain in Brazil. 
The fifth article, Human displacement and social recognition: the working conditions and relations of refugees and displaced people in Brazil, analyzes the process of inclusion and social recognition of displaced people and refugees from various countries, including Haiti, Syria, and Venezuela, through the qualitative analysis of approximately 300 unstructured interviews and psychosocial consultations performed with migrants and refugees in the Brazilian city of Curitiba. The authors adopted the category of "social recognition" proposed by Hegel based on the centrality of work being a foundation of social recognition. Their results indicate a precarious inclusion of refugees and immigrants in the workplace with evidence of working conditions similar to "paid slavery" and the experiences of social injustice and psychological distress.

The sixth article, Immigration as practice of organization: discussion about practices of organization, displacement, and integration of Haitian immigrants in the Goiânia Metropolitan Region, in Goiás, Brazil, analyzed Haitian migration with Administration theory. The techniques of life history and observation were used to detail the everyday activities of Haitian immigrants in the Goiânia metropolitan region. One conclusion was that displacement practices are deeply intertwined with organizational practices. An overall finding was that the process of displacement of Haitian immigrants is an ongoing phenomenon involving different dimensions of events, with international, national, and community displacement. In addition, this research expanded migratory analyses to the region of Goiás, Brazil.

The seventh article, Political exile in the post-2019 Brazilian context: history of the exile and work-existence/resistance of a Brazilian intellectual, used the life history methodology to better understand the situation of Brazilians who were forced to move from their own country due to political, social, professional and personal conflicts with contemporary neo-fascism. Their disagreements are based on contemporary neo-fascism's anti-intellectualism, homeland notion, patriarchal tradition, unreality, mythical past veneration, and disarticulation of public and union welfare. One highlight discussed in this article is the psychological importance of work due to its centrality as a main dimension of human life, a way to insert oneself into society, a source of identity, and a means of social mobility.

The last five articles examine ways in which refugees have been integrated and acculturated into Brazilian society often through the assistance of NGOs or through the efforts of managers in the workplace. In the eighth article, Refugees right to work: the characteristics of Brazilian migration policies from the end of World War II to 2019, the authors interviewed immigrants welcomed by the African Business Angel Network, a NGO in the state of Minas Gerais. They utilized semi-structured interview scripts with the results being subjected to content analysis. Results found that all immigrants needed less time than was expected to get a job which contributed to meaningful lives for these refugees and fuller access to citizen's rights. This research emphasized the importance of solid partnerships between the private and public sectors to help refugees find employment and integrate into society.

The ninth article, Integration of refugees involving organizational managers' experiences, utilized content analysis of semi-structured interviews of 5 managers in the city of São Paulo. Results indicated that in the companies studied, there were no formal Human Resource practices related to refugees. Some of the managers did reserve employee positions for the refugee population in an effort to have an informal diversity policy. These managers did recognize the importance of integrating refugees into their organization and the benefits of the diversity of refugees' experiences. Additional benefits experienced by the organization included willpower, gratitude, creativity, talent, company reputation, and professional engagement. Nonetheless, language issues, difficulty in proving titles, cultural differences, and psychological trauma were observed to be barriers to effective integration and inclusion in the workplace. Furthermore, mediation organizations were indispensable in preparing refugees with finding employment and integrating them into the workplace.

The tenth article, Acculturation and employment dynamics in a Brazilian NGO aimed at Haitian refugees' social integration, examined the activities of a NGO that focused on helping Haitian refugees. The authors utilized content analysis of in-depth interviews with the administrators, along with observations and analysis of documents, and found that the process of employment and acculturation are inseparable. The intercultural seminars, Portuguese language courses, conversation circles, mediated job interviews, and company visits after employment were all found to provide practical insights from an administrative perspective for other social entrepreneurs and legislators wishing to structure excellent programs such as this one. 
The eleventh article The role of social protection structures in the economic integration of refugees: analysis of Syrian refugees in the city of São Paulo, utilized interviews with refugees and social workers, an analysis of documents from NGOs and the Brazilian government along with ethnographic methods, to assess the safety net structure utilized by Syrian refugees in São Paulo. Syrian refugees have relied upon a complex, informal network comprised of the informal workplace, support from the Arab community, social assistance, and support provided by the mosques.

The twelfth article, Immaterial labor and civil society organizations: an alternative to refugee ways of working and living, utilized cartography, in-depth interviews of refugees, semi-structured interviews with representatives of 3 organizations, and information gleaned from flyers and the content of virtual social networks. The following important dimensions emerged as important variables in the integration of refugees: the actions of NGOs or Civil Society Organizations, reinvention of the refugee's ways of living and working and the refugee's route. Finally, immaterial labor and cooperation networks were seen as critical in helping refugees reinvent their ways of living and working.

We hope that the research presented in this special issue will increase interest in this important topic and lead to additional future research related to the barriers to the integration and acculturation that refugees face. Likewise, we hope this promotes more research related to the ways in which integration into society can be facilitated through work, through the assistance of NGOs, and through favorable government policies resulting in positive outcomes for refugees and displaced persons. 


\section{REFERENCES}

Ager, A., \& Strang, A. (2008). Understanding Integration: A conceptual framework. Journal of Refugee Studies, 21(2), 166-191. Retrieved from https://doi.org/10.1093/jrs/fen016-

International Organization for Migration. (2021). Home Page. Retrieved from https://www.iom.int/

Macrotrends. (2021). Brazil Refugee Statistics 1969-2021. Retrieved from https://www.macrotrends.net/countries/BRA/brazil/refugee-statistics
Rueda, M. (2020, October 07). Venezuelans brave 'brutal' migrant route made tougher by pandemic. BBC News. Retrieved from https:// www.bbc.com/news/world-latin-america-54418542

United Nations High Commissioner for Refugees. (2020). Venezuela Situation. Retrieved from https://www.unhcr.org/venezuela-emergency.html

United Nations High Commissioner for Refugees. (2021). Home Page. Retrieved from https://www.unhcr.org/en-us/

Ph.D. Sharon L. Segrest

ORCID: https://orcid.org/0000-0002-3693-8565

Ph.D. in Management from Florida State University; Master of Business Administration from Meredith College; Bachelor of Science in Marketing from the University of North Carolina at Chapel Hill; Professor of Management in the Muma College of Business at the University of South Florida, Tampa, $\mathrm{FL}$ - USA; She was elected to serve on the board of directors of the Southern Management Association; She serves on the board of ReBootKamp, an immersive code bootcamp which helps train refugees and others in Jordan, Palestine, and Tunisia. E-mail: ssegrest@usf.edu

Ph.D. Amy E. Hurley-Hanson

ORCID: https://orcid.org/0000-0002-4263-1885

Ph.D. in Management from New York University; Master of Business Administration from New York Institute of Technology; Bachelor of Science in Management from the University of Florida; Professor of Management in the George L. Argyros School of Business and Economics at Chapman University, Orange, CA - USA; She is the co-author of Autism in the Workplace Creating Positive Outcomes for Generation A published in 2020 as part of the Palgrave Explorations in Workplace Stigma series; She is the series editor of Emerald Studies in Workplace Neurodiversity. E-mail: ahurley@chapman.edu

Ph.D. Cristina M. Giannantonio ORCID: https://orcid.org/0000-0003-0784-1892

Ph.D. in Human Resource Management from the University of Maryland; Master of Business Administration from the University of Maryland; Bachelor of Science in Personnel and Labor Relations from the University of Maryland; Professor of Human Resource Management in the George L. Argyros School of Business and Economics at Chapman University, Orange, CA - USA; She is the co-author of Autism in the Workplace Creating Positive Outcomes for Generation A published in 2020 as part of the Palgrave Explorations in Workplace Stigma series; She is the series editor of Emerald Studies in Workplace Neurodiversity. E-mail: giannant@chapman.edu 